\title{
THE EFFECTS OF PERCEIVED SATISFACTION WITH SERVICE RECOVERY EFFORTS: A STUDY IN A HOTEL SETTING
}

\author{
Estrella Díaz, Mar Gómez, David Martín-Consuegra, Arturo Molina
}

\section{Introduction}

Innovation and the adoption of new business practices related to customer satisfaction are essential to improve social performance and sustainability, specifically in the tourism sector. While some tourism companies have developed new work strategies, it is difficult to consider issues such as quality certification, environmental policies, human resource training, or customer service norms, among other aspects. For example, in the case of hotels and restaurants, improved sustainability policies have been promoted through regulations and special actions (such as the ITQ 2000 \& RS norm), which generate more effective approaches to planning, innovation and customers and stakeholder relations (Buckley, 2012). Therefore, corporate model innovation is essential, and it must consider, as a fundamental element, the satisfaction of direct customers.

Numerous studies on customer satisfaction and relations management have been conducted in recent years as a result of company efforts aimed at offering quality services to target populations via quality certification. However, errors or customer complaints have often arisen through service provision processes. More specifically, it is important to note that within the service sector, the hospitality sector involves a high degree of personal contact between hotel staff and customers, during which various misunderstandings can result in service failures (Lewis \& McCann, 2004). Thus, failed service provisions are viewed as lower quality services, causing potential negative effects on customer satisfaction, future consumption choices, and word-of-mouth communication (WOM) (Morrisson \& Huppertz, 2010). Tourists and customers of hotel establishments typically have excessively high standards and expect hotels to achieve such standards, e.g., sustainability (Doran \& Larsen, 2014). To minimize the negative effects of previous failures, companies can apply service recovery strategies that are designed to address problems and unsatisfied customers to maintain customer loyalty to the company (Miller, Craighead, \& Karwan, 2000).

In this context, service recovery paradox (SRP) has become a key issue for companies in the competitive market place (Petnji, Marimon, \& Casadesus, 2013). SRP is not a new concept, but from years researchers have been trying to solve the existence and standardize this phenomenon. They have been consistently trying to identify reasons why and how successful service recovery may cancel the impact of service failure (Krishna, Dangayach, \& Sharma, 2014). A growing framework of literature has analyzed the relationships between service quality/recovery, satisfaction and loyalty, however few recent field empirical studies have addressed the influence of service failure/recovery encounters on customer evaluations in the hospitality industry. Specifically, there is a number of studies that have examined consumer satisfaction and recovery strategies in the context of the service sector (Chang \& Chang, 2010; Kim \& Jang, 2014; Río, Vázquez, \& Díaz, 2009; Sánchez, Pieters, Zeelenberg, \& Bigné, 2012) and in hotels (Mount, 2012; Mount \& Mattila, 2009). The major limitation is most of the research in this area has been exploratory, scenario-based experiments and non-generalizable, and the outcome of the theoretical and empirical results of these studies appeared to be contradictory (Petnji et al., 2013). Additionally, few studies have examined instances of service failure and relationships between system failure recovery and effects on future hotel customer behaviors. The study of Mount (2012) introduces methods to calculate dollar amounts for revenue recovered through recovery efforts in the hotel industry, but this research does not measure 
the actual future behavior of responding guests. By other hand, following the research outcomes of Boshoff (2005), researchers may assess the validity and reliability of RECOVSAT (an instrument to measure satisfaction with service recovery) in other service industries, such as the hospitality industry. Furthermore, Krishna et al. (2014) state that even after so many researches, they cannot conclude the existence of SRP, because SRP phenomenon needs to be further explored to give answer for various questions such as cultural difference. Moreover, limited research of service recovery is focused on the customer perception (Krishna et al., 2014).

Following the previous literature (e.g. Kim \& Jang, 2014), this research is justified by the calls for more studies investigating the effectiveness of recovery efforts, extending previous research on post-recovery satisfaction and behavioral outcomes with a field study on the hospitality industry in a Western country, based on three main reasons: (1) it would be better to investigate if customers of different services would display similar behavior; (2) the previous findings cannot be generalized to other industries until further empirical studies are conducted and multi-item measures are used; and (3) while they claim that it will be interesting to see the findings gleaned from a similar study conducted on hotel guests from a European environment, there are no relevant studies following their call yet. Thus, the main objective of this work is to examine empirically the relationship between service recovery strategies following hotel service failures and their effects on consumer satisfaction and actual future behavior in Spain. The study examines the hospitality sector given this industry's focus on inspiring feelings of customer satisfaction via service recovery strategies. The results and primary conclusions and management implications of this study are presented in this research article.

\section{Theoretical Framework}

Services play a significant role in the dynamic economy (Singhal, Krishna, \& Lazarus, 2013) and it shows an intense research and debate (Mount \& Mattila, 2009). Because of their intangible nature, there is a possibility of failures from both the operational and the employee perspective (Petnji et al., 2013). Maintaining good relationships between companies and customers is an important issue for academics and practitioners due to the rise of service orientation (Lin, Wang, \& Chang, 2011). However, in spite of this positioning, service failures are inevitable, even in the best organizations (Mount \& Mattila, 2009). Service failures are defined as a disaster of the core service, and several consequences can be derived: dissatisfaction or a declined customer confidence, among others (Miller et al., 2000). For most companies, service failure is the main reason for the loss of actual customers. Thus, service providers should learn how to respond to the various types of service failures (Lin et al., 2011). On occasion, service provision failures occur when suppliers cannot offer a service that would meet consumer expectations.

The service provider can satisfy the customer if a favorable response to the customer's expectations is given, although appropriate responses vary depending on sociodemographic factors such as gender or age, paradigms of sustainable tourism or approaches to service recovery execution (Boo, Mattila, \& Tan, 2013; Cambra-Fierro, Berbel-Pineda, RuizBenítez, \& Vázquez-Carrasco, 2013; Ferguson \& Moreno-Alarcón, 2015; Kwon \& Jang, 2012). Service recovery refers to the actions that an organization or service supplier makes in response to service failure (Parasuraman, Zeithaml, \& Malhotra, 2005; Tax \& Brown, 2000). Marketing should lead to a firm-wide customer orientation, especially in service firms to manage service recovery. In recent years, extant literature present several contributions to service recovery, including both theoretical, and empirical assessments. Moreover, some authors have even quantified the service recovery efforts to provide a numerical measure to the effects of recovery on intent to return (Mount, 2012).

Additionally, service recovery strategies have traditionally been presented as key organizational elements, and especially in relation to the hospitality, banking, health care, retail, air transport sectors, tourism, and leisure and hotels (Krishna et al., 2014; Lin et al., 2011; Moreno, Hudson, \& Aguilar, 2006; VázquezCasielles, Suárez-Álvarez \& Díaz-Martín, 2010; Weber \& Sparks, 2010).

\subsection{Service Recovery, Customer Satisfaction and Subsequent Behaviors}

A recovery strategy is a process through which a supplier maintains customer 
satisfaction following a service provision failure (Alexander, 2002). Some researchers design recovery processes to get maximum advantage of service recovery (Krishna et al., 2014). Recovery strategies serve as the most important determining factors of service quality and customer retention, having a direct impact on company profitability (Fig. 1).

Zeithaml, Berry and Parasuraman (1993) stated that customers are more emotionally involved and engaged when a recovery strategy is delivered than when original services are provided. Recovery situations have given rise to a complex phenomenon known as the SRP. This term refers to a phenomenon through which a customer, after receiving a failed service, filing a complaint with the company and being addressed through a satisfactory recovery response, experiences a level of satisfaction with the final service that is higher than the satisfaction that he would have achieved if the service were provided correctly from the start. In turn, this customer will become more loyal to the company and more likely recommend the company to third parties (McCollough, 2010). Satisfaction and customer loyalty are relevant elements for business survival (Vildová et al., 2015). Nowadays, there is a growing body of empirical evidence that confirms the contribution of satisfactory service recovery on repurchase intention and WOM perceptions (Boshoff, 2005). Previous studies suggest that a highly effective service recovery provides a change to achieve higher satisfaction and customer retention (Lin et al., 2011). Successful service recovery can enhance customers' perceptions enhancing customer satisfaction, building longer customer relationships and leading to positive WOM (Michel, Bowen, \& Johnston, 2009). If not, many negative outcomes will result, such as a negative WOM (Tax \& Brown, 2000). The relationship among customer's perceptions of service recovery with satisfaction and customer retention has been also studied taking into account the quality management assurance certification as ISO 9001 (Petnji et al., 2013).

\section{Fig. 1: Strategies of service recovery and subsequent behaviors}

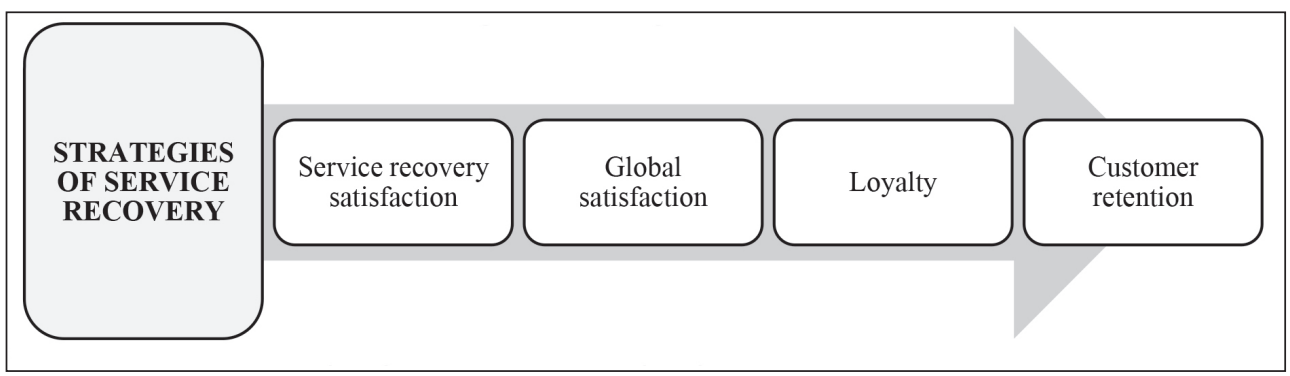

Source: Based on Miller et al. (2000) and Varela-Neira et al. (2010)

The marketing literature cites two approaches to consumer satisfaction measurement: cognitive (Fornell, 1992), and affective or emotional (Giese \& Cote, 2000). According to the cognitive perspective, satisfaction is defined as a consumer response based on the consumer's evaluation of the relationship between the resulting product and a standard for comparison (Oliver, 1980). Among the cognitive theoretical approaches, the expectations disconfirmation approach is particularly noteworthy (Yoon \& Kim, 2000). According to this perspective, the individual develops expectations of a product both prior to purchase and after the consumption experience, and thus the individual compares the resulting product with his preconceived expectations. Thus, consumer satisfaction serves as a basis for the formation of subsequent attitudes and intentions. This perspective can be applied to tourism services due to expectations that are generated during purchases and due to expectations of enjoyment following the attainment services. Unlike prior approximations, the affective approach includes conceptualizations that define this phenomenon as a strictly emotional consumer response reflected through feelings, with the 
result being an experience with a product or with certain product attributes (Giese \& Cote, 2000). In more recent studies, a combination of both approaches has typically been applied (Johnson \& Grayson, 2005; Varela-Neira, Vázquez-Casielles, \& Iglesias-Argüelles, 2010).

On the other hand, consumer loyalty can be defined as non-random behaviors that express in-time factors depending on psychological processes and brand commitments, implying return purchases and favorable attitudes towards the product (Flavián \& Guinalíu, 2006). This phenomenon has been examined through two different approaches. From an attitudes-based perspective, feelings motivate the customer to establish commitment towards a product or service, which is measured by the customer's intention to repurchase, resistance to superior alternatives, price tolerance and intention to recommend the product or service (VázquezCasielles et al., 2010). On the other hand, loyalty from a behavioral perspective is based on other aspects that are indicative of the purchasing act such as the establishment visitation frequencies or expenditure percentages, thereby defining loyal customers as those who repurchase a brand or product. Consequently, loyalty is considered to be one of the main factors that supports company success and causes reductions in future transactions and sustainability overtime (Flavián \& Guinalíu, 2006). In this competitive marketplace, customer loyalty is critical to conducting business (Komunda \& Osarenkhoe, 2012). There are some authors that contemplate both behavioral and attitudinal loyalty (Petnji et al., 2013).

Finally, WOM communication can be defined as informal conversations with other consumers on the properties, uses, and characteristics of goods, services and providers (Westbrook, 1987). Customers who experience service failure tell the incident to other ten people, while those not experiencing a negative service only tell to five people (Oliver, 2010). WOM has been studied using positive and negative approaches, with positive WOM serving as a manifestation or dimension of consumer loyalty towards a given product or establishment (Molinari, Abratt, \& Dion, 2008). Therefore, positive WOM is configured as a consumer's possible reaction to a satisfactory consumption experience. A number of studies have empirically found such a relationship between satisfaction and WOM (East, Hammond, \& Lomax, 2008).
In general terms, it has been proven in the literature that a higher degree of consumer satisfaction promotes higher levels of individual loyalty (Belás \& Gabčová, 2016; McCollough, 2010). Positive effects of satisfaction on loyalty are reflected in consumer intentions to repurchase a product or service or to engage in positive WOM (Weber \& Sparks, 2010). Consequently, companies can benefit from securing a base of stable customers or by reducing marketing costs (Doorn \& Verhoef, 2008), leaving the organization in a more competitive position (Kim, Kim, \& Kim, 2009). In this context, the following research questions are studied:

RQ1: Is there a direct and positive relationship between satisfaction, failed service recovery strategies and overall consumer satisfaction?

RQ2: Is there a direct and positive relationship between consumer intentions to repurchase and overall consumer satisfaction after service provisions fail and are recovered?

RQ3: Is there a direct and positive relationship between positive WOM about a service provider and consumer intentions to repurchase after a failed and recovered service is encountered?

\section{Method}

To address the proposed questions, an empirical study of the hospitality industry was conducted. Scenarios methodology has been frequently used in service failure and recovery research (i.e., Kim \& Jang, 2014; Liu \& Mattila, 2015; Sengupta et al., 2015). However, Chebat and Slusarczyk (2005) highlight two major limitations for scenarios methodology used in service failure and recovery studies. Firstly, the reaction to the scenarios is not to real service failure. Secondly, manipulated lab situations don't reflect customers' actual behavior. Because this study focuses on evaluating the effectiveness of service recovery actions in response to real service failure, data were collected using critical incident technique within a questionnaire survey design, (i.e., any event that significantly deviates, both positively and negatively, from normal expectations) rather than a simulated scenariobased procedure. The study focuses on negative critical incidents (Gardial, Flint, \& Woodruff, 1996), i.e., the most recent problems of special relevance that customers had experienced throughout their stay at a hotel. 
Since this study focused on the service recovery effects within the hospitality industry, the targets were adults of both genders older than 18 years of age who had stayed at least one night at one of the nine 4-star hotels or four 5-star hotels in the Historic City of Toledo (Spain), which has the elite title of UNESCO World Heritage City. Additionally, they had complained for problems that occurred during the stay in the hotel and have perceived some type of recovery effort. During the fieldwork, an average occupancy of $81.42 \%$ with an average guest stay of 1.6 nights was observed (INE, 2015). In order to avoid response biases, three interviewers spent two months conducting a random sampling in different places and situations within the city (hotels' surroundings, historical center, principal monuments, and popular restaurants' surroundings). The questionnaire was applied on different days and times. If the subject approached was not stayed in any of the 4-star or 5-star hotels, had not any complaint or was not experienced any recovery effort, the interviewers thanked them for their time and concluded the interview. The respondents were not offered an incentive for participating. No significant variations in data collection across the different interviewers or systematic differences in samples by locations were found before adopting a single sample for further analysis.

A total of 986 clients of those hotels were intercepted. Unfortunately, 698 interviewees did not have a service failure experience or was not solved yet, 14 interviewees did have a complaint but did not completely finish the survey, and 274 questionnaires were completed and valid from clients who had experienced failed service provisions. Of the 274 consumers surveyed, who are representative of the study population, $60.1 \%$ were male and $39.9 \%$ were female. Over $56 \%$ had graduated from university and had an average age of 34.3 years. The age distribution was: $23,0 \%$ between 18 and 30 years of age, $35.4 \%$ between 31 and 40 years of age, $23.7 \%$ between 41 and 50 years of age and $17.9 \%$ fifty years of age or older. Most of the respondents travelled two-three times a year, and their major reservation method was to use a travel agency. The majority of the service failures $(72.5 \%)$ were personnel-related failures, i.e., slow servicing, and only $27.5 \%$ percent were other failures.

For data collection purposes, a structured questionnaire was used. The study questionnaire is divided into sections. The first section includes socio-demographic questions. The second bloc contains questions on customer relations with respective hotel establishments and on critical incidents experienced. A final section includes measurement scales related to the main objective of the study. The measurement scale used was adapted from scales used in prior studies. In all cases, Likert 7 point scales were used to measure the following variables ( 1 = completely disagree, 7 = completely agree).

Literature review presents different instruments to assess customer satisfaction with their service recovery efforts. In this sense, RECOVSAT is a valid instrument for service managers to assess customer satisfaction with service recovery efforts (Boshoff, 2005). This author highlights the multi-dimensional nature of service recovery. Therefore, service recovery strategies were measured using RECOVSAT that was developed and redefined by Boshoff (1999; 2005). The scale is composed of six dimensions: communication, training, response, apology, explanation and tangible features (Tab. 1). A six-item instrument adapted from the Oliver (1980) scale was used to measure consumer satisfaction with the service received. Repurchase intention was measured based on four items according to the Reynolds and Beatty (1999) scale. The last dimension, which includes three items, refers to positive WOM generated after the service is delivered (see the Maxham and Netemeyer (2002) scale and Zeithaml, Berry and Parasuraman (1996) scale). Individual items for these constructs are listed in the Appendix.

The data obtained will serve to test the research questions proposed in the theoretical framework of this research, which uses multivariate techniques. To be more precise, the method used has been structural equations. This will allow authors to present evidence of the internal structure of the constructs, that is, its reliability and validity. Following recommendations by Hair, Black, Babin, and Anderson (2009), and Anderson and Gerbing (1988), confirmatory factor analysis was done using the EQS 6.1 software.

\section{Results and Discussion}

A model of structural equations was used to answer the research questions proposed (Hair et al., 2009; Anderson \& Gerbing, 1988). Before testing the structural model the measurement model needs evaluation, Bagozzi's (1984) 


\section{Tab. 1: Dimensions of the RECOVSAT scale}

\begin{tabular}{l|l} 
Dimensions & Activities developed \\
\hline COMMUNICATION & $\begin{array}{l}\text { Hotel employees communicated clearly with customers who had } \\
\text { experienced a failure in service, answered questions to understand the } \\
\text { situation, exhibited a receptive attitude and were honest in their efforts to } \\
\text { solve the problem. }\end{array}$ \\
\hline TRAINING & $\begin{array}{l}\text { Hotel employees who the received customer complaint solved the problem } \\
\text { and did not need to solicit assistance from colleagues or hotel staff } \\
\text { members. }\end{array}$ \\
\hline RESPONSE & $\begin{array}{l}\text { The hotel that failed in its service provision either provided a written } \\
\text { response to the unsatisfied customer on the state of the problem or sent } \\
\text { a written apology. }\end{array}$ \\
\hline APOLOGY & $\begin{array}{l}\text { The employees who committed the service failure politely apologized to } \\
\text { address economic losses suffered by the customer. }\end{array}$ \\
\hline EXPLANATION & $\begin{array}{l}\text { The employees who committed the service failure provided an explanation } \\
\text { for the error that the customer viewed as satisfactory. }\end{array}$ \\
\hline TANGIBLE FEATURES & $\begin{array}{l}\text { The hotel employees who committed the service failure offered } \\
\text { compensation for inconveniences caused (refund, exchange of goods/ } \\
\text { services for similar services or discounts on future purchases). }\end{array}$ \\
\hline
\end{tabular}

Source: Adapted from Boshoff (2005)

methodology for validating multidimensional constructs was used to assess the scale. This study assesses the reliability and validity of all the constructs through an overall confirmatory measurement model (Tab. 2). As evidence of convergent validity, the confirmatory factor analysis results indicate that all items are significantly $(p<0.01)$ related to their hypothesized factors, that the size of all of the standardized loadings are greater than 0.60 and that the averages of the item-to-factor loadings are greater than 0.70 .

The findings also demonstrate the high internal consistency of the constructs. In each case, the Cronbach's alpha exceeds Nunnally and Bernstein's (1994) recommended threshold of 0.70 . Composite reliability represents the shared variance among a set of observed variables measuring an underlying construct (Fornell \& Larcker, 1981). A composite reliability of at least 0.60 is generally considered desirable. This requirement is met for every factor. The average variance extracted (AVE) is also calculated for each construct, resulting in AVEs greater than 0.50 (Fornell \& Larcker, 1981).

Evidence for the discriminant validity of the measures is provided in two ways (Tab. 3). First, none of the $95 \%$ confidence intervals of the individual elements of the latent factor correlation matrix contain a value of 1.0 (Anderson \& Gerbing, 1988). Second, the shared variance between the pairs of constructs is always less than the corresponding AVE (Fornell \& Larcker, 1981). Overall, these results indicate that the measures possess adequate reliability and validity.

The results of the SEM are summarized in Tab. 4. The structural model provides a good fit to the data based on a number of fit statistics (S-B $\chi^{2}=565.335, p=0.00$; Root Mean Square Error of Approximation (RMSEA) $=0.054$; Normed Fit Index $(\mathrm{NFI})=0.938$; NonNormed Fit Index (NNFI) $=0.943$; Comparative Fit Index $(\mathrm{CFI})=0.964$; and Incremental Fit Index $(\mathrm{IFI})=0.954)$. Fig. 2 presents the factorial loads or intensities relative to existing relationships between various failed service recovery and customer satisfaction features. The figure shows that service recovery strategy satisfaction is directly and positively related to overall customer satisfaction. This answers the first research question. When hotel managers or employees commit a service failure towards a customer but respond appropriately with adequate service recovery strategies, the customer experiences an increase in consumer satisfaction. Recovery strategies carried out by hotel managers or employees can be measured 


\begin{tabular}{|c|c|c|c|c|c|c|c|}
\hline \multirow[b]{2}{*}{ Item } & \multicolumn{3}{|c|}{ RELIABILITY } & \multicolumn{2}{|c|}{$\begin{array}{l}\text { CONVERGENT } \\
\text { VALIDITY }\end{array}$} & \multicolumn{2}{|c|}{ DISCRIMINANT VALIDITY } \\
\hline & $\begin{array}{l}\text { Cronbach's } \\
\text { Alpha ( } \alpha)\end{array}$ & CR & AVE & $\begin{array}{l}\text { Factor } \\
\text { loading }\end{array}$ & $\begin{array}{l}\text { Loading } \\
\text { Average }\end{array}$ & Critical pair & $\begin{array}{c}\text { Confidence Interval } \\
\text { Test } \\
\text { Variance Extracted } \\
\text { Test } \\
\end{array}$ \\
\hline $\begin{array}{l}\text { COM1 } \\
\text { COM2 } \\
\text { COM3 } \\
\text { COM4 } \\
\text { COM5 }\end{array}$ & 0.94 & 0.93 & 0.75 & $\begin{array}{l}0.858^{* * *} \\
0.944^{* * *} \\
0.921^{* * *} \\
0.799^{* * *} \\
0.813^{* * *}\end{array}$ & 0.867 & $\begin{array}{l}\text { SAT,INT } \\
\text { Corr }=0.79 \\
\text { Corr }^{2}=0.63\end{array}$ & $\begin{array}{l}\text { Confidence Interval } \\
\text { for }+/-2 \sigma=[0.69,0.90] \\
\text { Corr }^{2}{ }_{\mathrm{SAAL}}<\mathrm{AVE}_{\mathrm{AL}}<\mathrm{AVE}_{\mathrm{SA}}\end{array}$ \\
\hline $\begin{array}{l}\text { TRA1 } \\
\text { TRA2 } \\
\text { TRA3 } \\
\end{array}$ & 0.91 & 0.88 & 0.72 & $\begin{array}{l}0.848^{* * *} \\
0.963^{\star * *} \\
0.720^{\star * *}\end{array}$ & 0.844 & & \\
\hline $\begin{array}{l}\text { RES1 } \\
\text { RES2 }\end{array}$ & 0.90 & 0.84 & 0.72 & $\begin{array}{l}0.849^{* * *} \\
0.858^{* * *}\end{array}$ & 0.853 & & \\
\hline $\begin{array}{l}\text { APO1 } \\
\text { APO2 } \\
\text { APO3 }\end{array}$ & 0.91 & 0.88 & 0.71 & $\begin{array}{l}0.818^{* * *} \\
0.743^{* * *} \\
0.954^{* * *}\end{array}$ & 0.838 & & \\
\hline $\begin{array}{l}\text { EXP1 } \\
\text { EXP2 }\end{array}$ & 0.92 & 0.89 & 0.80 & $\begin{array}{l}0.935^{\star * *} \\
0.863^{* * *}\end{array}$ & 0.899 & & \\
\hline $\begin{array}{l}\text { TAN1 } \\
\text { TAN2 } \\
\end{array}$ & 0.89 & 0.83 & 0.71 & $\begin{array}{l}0.904^{* * *} \\
0.789^{* * *}\end{array}$ & 0.846 & & \\
\hline $\begin{array}{l}\text { SAT1 } \\
\text { SAT2 } \\
\text { SAT3 } \\
\text { SAT4 } \\
\text { SAT5 } \\
\text { SAT6 }\end{array}$ & 0.92 & 0.93 & 0.72 & 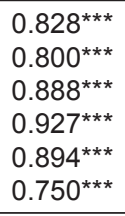 & 0.848 & & \\
\hline $\begin{array}{l}\text { INT1 } \\
\text { INT2 } \\
\text { INT3 } \\
\text { INT4 }\end{array}$ & 0.93 & 0.91 & 0.73 & $\begin{array}{l}0.849^{* * *} \\
0.863^{* * *} \\
0.818^{* * *} \\
0.906^{* * *}\end{array}$ & 0.859 & & \\
\hline $\begin{array}{l}\text { WOM1 } \\
\text { WOM2 } \\
\text { WOM3 }\end{array}$ & 0.87 & 0.87 & 0.69 & $\begin{array}{l}0.815^{\star \star *} \\
0.889^{* \star *} \\
0.789^{* \star *}\end{array}$ & 0.831 & & \\
\hline
\end{tabular}

Source: own

Note: CR: Composite Reliability, AVE: Average Variance Extracted, COM: communication, TRA: training, RES: response, APO: apology, EXP: explanation, TAN: tangible features, SAT: satisfaction, INT: repurchase intention, WOM: word-of-mouth. 


\section{Marketing a obchod}

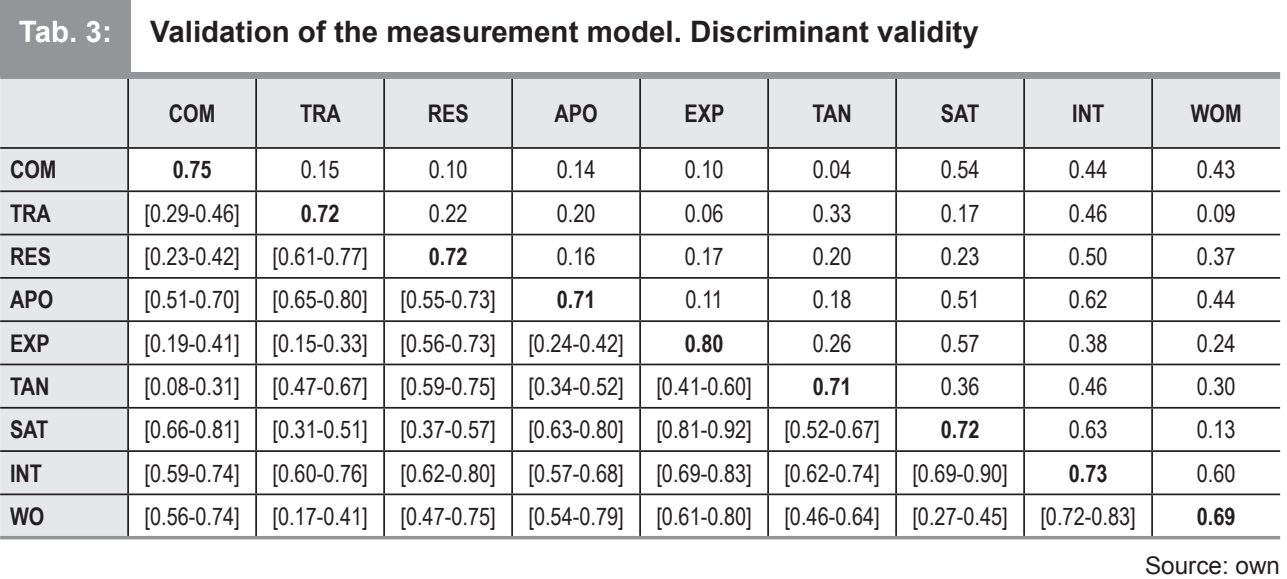

Note: Diagonal represents the average variance extracted; while above the diagonal the shared variance (squared correlations) is represented. Below the diagonal the $95 \%$ confidence interval for the estimated factors correlations is provided.

\section{Fig. 2: Model contrast}

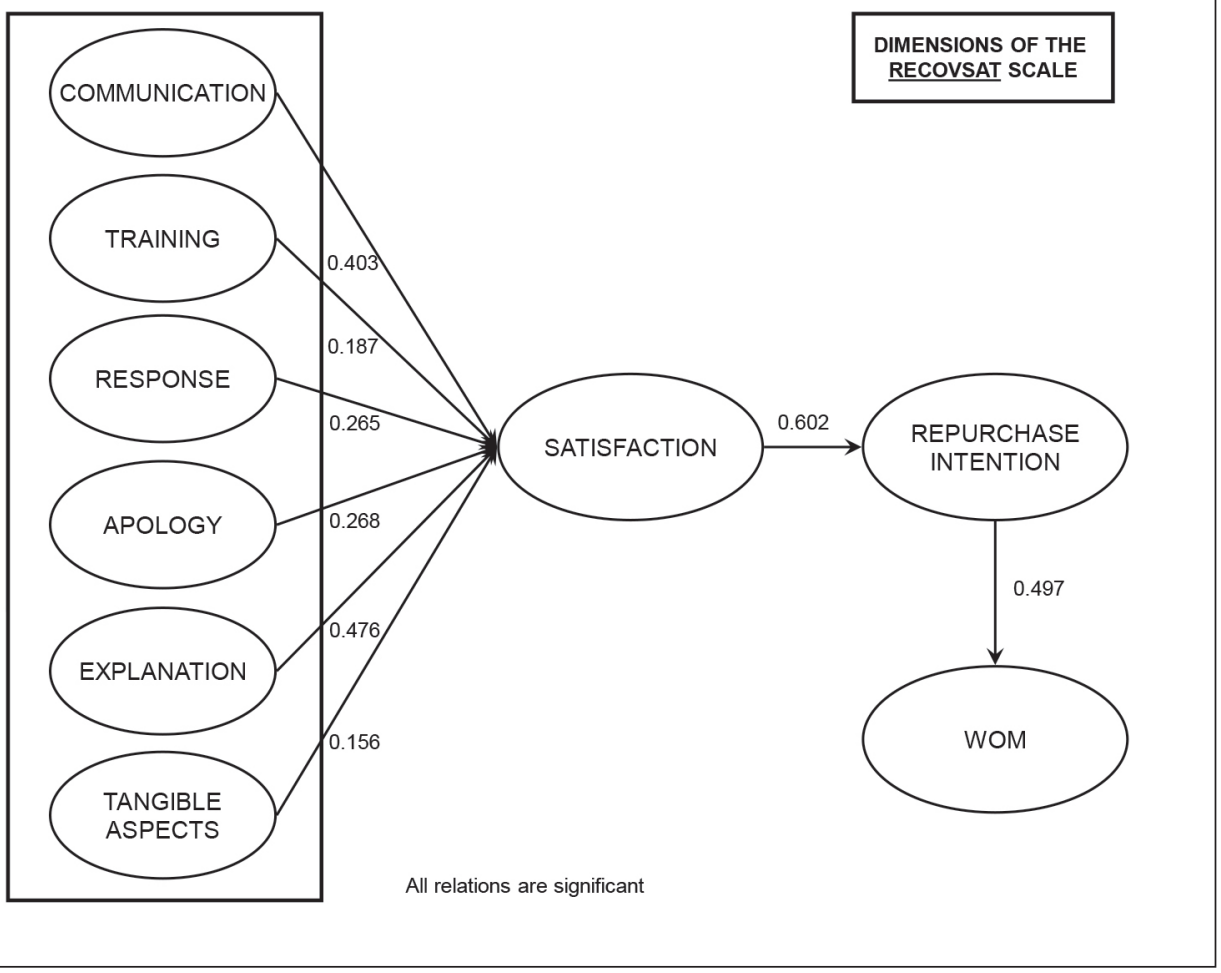

Source: own 
based on six elements: tangible features $(\beta=0.156, p<0.01$ ), i.e., compensation, an adequate explanation made to the customer by the employee who conducted the service failure $(\beta=0.476, p<0.01)$, an apology $(\beta=0.268$, $p<0.01)$, a positive response to the employee who conducted the service failure $(\beta=0.265$, $p<0.01)$, sophisticated hotel staff training on responding to service failures $(\beta=0.187$, $p<0.01)$ and, finally, adequate communication between the employee responsible for the service failure and the dissatisfied customer $(\beta=0.403, p<0.01)$.

Regarding the second research question, Fig. 2 depicts a strong relationship between overall consumer satisfaction and service recovery and repurchase intention $(\beta=0.602$, $p<0.01)$. This relationship is positive and direct, proving that higher degrees of overall customer satisfaction with service recovery strategies offered by hotel managers or employees result in greater degrees of repurchase intention from the customer who filed a complaint.

Finally, regarding the last research question, there is a positive and direct relationship between repurchase intention of customers who filed complaints and subsequent positive WOM communication from these customers $(\beta=0.497, p<0.01)$. Thus, higher degrees of repurchase intention among customers who received failed services will correlate with positive recommendations made about these hotels by the same customers to their peers. Additionally, Tab. 4 shows the impact of each construct, including the direct, indirect and total effects. Customer satisfaction also affects WOM through Repurchase Intentions, with a significant indirect effect $(\beta=0.299)$.

\section{Tab. 4: Statistics of model fit measures and the effects of each construct}

\begin{tabular}{|c|c|c|c|c|c|c|c|c|c|}
\hline \multicolumn{2}{|c|}{ 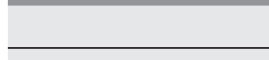 } & $\mathrm{X}^{2} / \mathrm{df}$ & NFI & NNFI & CFI & IFI & RMSEA & & \\
\hline \multicolumn{2}{|c|}{ Model value } & 2.446 & 0.938 & 0.943 & 0.964 & 0.954 & 0.054 & & \\
\hline \multicolumn{2}{|c|}{$\begin{array}{l}\text { Recommended } \\
\text { values }\end{array}$} & $\leq 3$ & $\geq 0.9$ & $\geq 0.9$ & $\geq 0.9$ & $\geq 0.9$ & $\leq 0.08$ & & \\
\hline & \multicolumn{3}{|c|}{ SATISFACTION } & \multicolumn{3}{|c|}{ REPURCHASE INTENTION } & \multicolumn{3}{|c|}{ WORD-OF-MOUTH } \\
\hline & Direct & Indirect & Total & Direct & Indirect & Total & Direct & Indirect & Total \\
\hline COM & 0.403 & & 0.403 & & 0.243 & 0.243 & & 0.121 & 0.121 \\
\hline TRA & 0.187 & & 0.187 & & 0.113 & 0.113 & & 0.056 & 0.056 \\
\hline RES & 0.265 & & 0.265 & & 0.159 & 0.159 & & 0.079 & 0.079 \\
\hline APO & 0.268 & & 0.268 & & 0.161 & 0.161 & & 0.081 & 0.081 \\
\hline EXP & 0.476 & & 0.476 & & 0.286 & 0.286 & & 0.142 & 0.142 \\
\hline TAN & 0.156 & & 0.156 & & 0.094 & 0.094 & & 0.047 & 0.047 \\
\hline SAT & & & & 0.602 & & 0.602 & & 0.299 & 0.299 \\
\hline INT & & & & & & & 0.497 & & 0.497 \\
\hline
\end{tabular}

In terms of the indirect effect of WOM, Explanation $(\beta=0.142)$ has the strongest effect, followed by Communication $(\beta=0.142$ ).

The results of the study reveal effective failed service strategies for increasing consumer satisfaction and repurchase intentions after requested service provision failures occur. The empirical results also show that communication and explanation are the dimensions of importance to consumers when they report a service failure to a service firm
(Boshoff, 2005). This finding is consistent with the findings of Sparks and Callan (1996), de Ruyter and Wetzels (2000), that the communication and explanation of the service provider can positively influence customer satisfaction. Communication with staff responsible for receiving complaints on defective service provisions directly affects service satisfaction and indirectly affects repurchase intentions and positive WOM through these latter variables. Therefore, 
training for hotel staff on ways to attend to service provision problems is imperative. The results also reveal a direct and significant effect on recovery strategies, responses, and apologies on service satisfaction and a mediating effect on future customer behaviors. Additionally, the importance of compensation through tangible features is also reflected in Boshoff (2005) conclusions and partially by Wirtz and Mattila (2004). Customer satisfaction has a positive impact on service recovery, leading to a highlevel of positive WOM behavior and repurchase intention. To improve this customer loyalty, hotel managers need policies and systems for service recovery with improved communication and explanation. A failure in reliability is failing once, failing in recovery is failing twice, and that is where the guest is lost. These findings are consistent with the outcomes of Komunda and Osarenkhoe (2012), that if this is not done, it is highly likely that dissatisfied customers will either change service provider or engage in negative WOM to the detriment of the hotel, leading to loss sales and profits (Johnston \& Michel, 2008). On the other hand, consumers who receive fair service recovery are more likely to book again and will send the guest away with a positive experience to share with others.

\section{Conclusions}

According to Oliver (2010), customer conflicts are inevitable; however, a powerful service recovery strategy can turn these conflicts into opportunities to improve performance and raise profitability. This study presents findings based on real service failure cases of an analysis of relationships between the failure recovery strategies and their effects on future customer behaviors in relation to hotel establishments. This work, using data collected from customers who have actually complained to a hotel establishment, stresses the importance of adequate service recovery strategies performed by hotel employees in shaping consumer behaviors following a service provision failure. Thus, customer satisfaction with hotel service recovery strategies affects customers' repurchase intentions and subsequent positive WOM recommendations.

Nowadays, developing and maintaining a relationship with new and existing customers has become a key business strategy. However, throughout the lifetime of customer relationships with a firm, unforeseen situations such as problems associated with product or service failures may occur and firms must effectively handle these problems to maintain customer satisfaction and loyalty (Boshoff, 2005; Marimon, Petnji, \& Casadesus, 2012). Service performances that fail to meet customer expectations implies that adequate service recoveries have to be in place to ensure customer satisfaction. As Zeithaml, Parasuraman and Berry (1990) state, "When a service problem does crop up, however, all is not lost, unless the company ignores it. In other words, by resolving the problem to the customer's satisfaction-by performing the service very right the second time-the company can significantly improve customer-retention rates" (p. 31). The results of this study equip hotel service providers with means of addressing service provision failures in ways that prevent double deviation (a failure of service provisions and recovery strategies). As well, by acting on explanatory variables, hotel service providers can attempt to recover discontented customers. Thus, the results of this study highlight the need to collect information on emotional reactions to failed service provisions.

Complaints are also a very useful form of market information that can be used to make strategic and tactful decisions (Nyer, 2000). It is thus necessary for companies to manage comprehensive complaint management systems to track issues or service failures that can cause customer dissatisfaction. The study also illustrates the effect of employee apologies and explanations on customer satisfaction and future behaviors. These two failed service recovery actions are not costly to implement, and given their ability to "restore" perception of services, they should be incorporated into recovery systems. Additionally, that experienced frontline staff can be trained in appropriate decision-making techniques that build upon their practical abilities and experience to provide these service recovery solutions that benefit both the customer and the organization. To achieve this, service recovery by frontline staff needs to be timely, reassuring, and empathic. Finally, management teams must recognize that it is not possible to establish an overall strategy for addressing service failures, as appropriate recovery actions will vary with each specific case. This study recommends designing recovery process in such a way to get maximum advantage of this 
phenomenon. Therefore, organizations should offer dissatisfied customers with the option to choose among various recovery options.

This study also presents various methodological limitations. First, the critical incident technique used to gather data is based on the recollection of past situations, and thus a "memory" bias may be present. Future research in this study area may apply different tools such as controlled experiments. It is also necessary to also comment on the cross-sectional nature of this study and on specific characteristics of the examined sector, which include significant degrees of price competition and seasonality. Future research may thus apply the model to other service spheres via longitudinal study to compare results for various time periods. Furthermore, data obtained through this study refer to only one type of service provider. The study results therefore cannot be generalized to other service providers or hotel establishments such as citybased hotels or business accommodations.

Future research efforts may use other moderating variables such as customer views regarding who is responsible for service failures (the company, the user or environmental factors), the timing of originating causes (stable or transitory) and levels of company control (complete or none). Finally, future research may examine cultural behavior differences between customer segments to determine how characteristics of customers that file complaints affect satisfaction levels or how external factors such as pricing or service provider traits affect customer responses to service failures.

\section{References}

Alexander, E. C. (2002). Consumer reactions to unethical service recovery. Journal of Business Ethics, 36(3), 223-237. doi:10.1023/A:1014086327876.

Anderson, J. C., \& Gerbing, D. W. (1988). Structural equation modelling in practice: a review and recommended two-step approach. Psychological Bulletin, 103(3), 411-423. doi:10.1037/0033-2909.103.3.411.

Bagozzi, R. P. (1984). Expectancyvalue attitude models: an analysis of critical measurement issues. International Journal of Research in Marketing, 1(4), 43-60. doi:10.1016/0167-8116(85)90021-7.

Belás, J., \& Gabčová, L. (2016). The relationship among customer satisfaction, loyalty and financial performance of commercial banks. E\&M Ekonomie a Management, 19(1), 132-147. doi:10.15240/tul/001/2016-1-010.

Boo, H. C., Mattila, A., \& Tan, C. Y. (2013). Effectiveness of recovery actions on deviant customer behavior. The moderating role of gender. International Journal of Hospitality Management, 35, 180-192. doi:10.1016/j. ijhm.2013.06.005.

Boshoff, C. (1999). RECOVSAT: An instrument to measure satisfaction with transaction specific service recovery. Journal of Service Research, 1(3), 236-249. doi:10.1177/109467059913005.

Boshoff, C. (2005). A reassessment and refinement of RECOVSAT: an instrument to measure satisfaction with transaction-specific service recovery. Managing Service Quality, 15(5), 410-425. doi:10.1108/09604520510617275.

Buckley, R. (2012). Sustainable tourism: research and reality. Annals of Tourism Research, 39(2), 528-546. doi:10.1016/j. annals.2012.02.003.

Cambra-Fierro, J., Berbel-Pineda, J. M., Ruiz-Benítez, R., \& Vázquez-Carrasco, R. (2013). Analysis of the moderating role of the gender variable in service recovery processes. Journal of Retailing and Consumer Services, 20(4), 408-418. doi:10.1016/j. jretconser.2012.11.008.

Chang, Y. W., \& Chang, Y. H. (2010). Does service recovery affect satisfaction and customer loyalty? An empirical study of airline services. Journal of Air Transport Management, 16(6), 340-342. doi:10.1016/j. jairtraman.2010.05.001.

Chebat, J., \& Slusarczyk, W. (2005). How emotions mediate the effects of perceived justice on loyalty in service recovery situations: an empirical study. Journal of Business Research, 58(5), 664-673. doi:10.1016/j. jbusres.2003.09.005.

de Ruyter, K., \&Wetzels, M. (2000). Customer equity considerations in service recovery: a cross-industry perspective. International Journal of Service Industry Management, 11(1), 91-108. doi:10.1108/09564230010310303.

Doorn, J., \& Verhoef, P. C. (2008). Critical incidents and the impact of satisfaction on customer share. Journal of Marketing, 72(3), 123-142. doi:10.1509/jmkg.72.4.123.

Doran, R., \& Larsen, S. (2014). Are we all environmental tourists now? The role of biases 
in social comparison across and within tourists, and their implications. Journal of Sustainable Tourism, 22(7), 1023-1036. doi:10.1080/09669 582.2013.836209.

East, R., Hammond, K., \& Lomax, W. (2008). Measuring the impact of positive and negative word-of-mouth on brand purchase probability. International Journal of Research in Marketing, 25(3), 215-224. doi:10.1016/j. ijresmar.2008.04.001.

Ferguson, L., \& Moreno-Alarcón, D. (2015). Gender and sustainable tourism: reflections on theory and practice. Journal of Sustainable Tourism, 23(3), 401-416. doi:10.1080/0966958 2.2014.957208.

Flavián, C., \& Guinalíu, M. (2006). Consumer trust, perceived security, and privacy policy: three basic elements of loyalty to a website. Industrial Management \& Data Systems, 106(5), 601-620. doi:10.1108/02635570610666403.

Fornell, C., \& Larcker, D. F. (1981). Evaluating structural equations models with unobservable variables and measurement error. Journal of Marketing Research, 18(1), 39-50. doi:10.2307/3151312.

Fornell, C. (1992). A national customer satisfaction barometer: the Swedish experience. Journal of Marketing, 56(1), 6-21. doi:10.2307/1252129.

Gardial, S. F., Flint, D. J., \& Woodruff, R. B. (1996). Trigger events: exploring the relationships between critical events and consumers' evaluations, standards, emotions, values and behavior. Journal of Consumer Satisfaction and Dissatisfaction and Complaining Behavior, 9, 35-51.

Giese, J. L., Cote, J. A. (2000). Defining consumer satisfaction. Academy of Marketing Science Review, 1, 1-27.

Hair, J. F., Black, W. C., Babin, B. J., \&Anderson, R. E. (2009). Multivariate Data Analysis. Upper Saddle River, New Jersey: Pearson Prentice-Hall.

INE. (2015). Hotel Occupancy Survey. Madrid: National Statistics Institute.

Johnson, D., \& Grayson, K. (2005). Cognitive and affective trust in service relationship. Journal of Business Research, 58(4), 500-507. doi:10.1016/s0148-2963(03)00140-1.

Johnston, R., \& Michel, S. (2008). Three outcomes of service recovery: customer recovery, process recovery and employee recovery. International Journal of Operations \& Production Management, 28(1), 79-99. doi:10.1108/01443570810841112.
Kim, J. H., \& Jang, S. C. (2014). A scenario-based experiment and a field study: A comparative examination for service failure and recovery. International Journal of Hospitality Management, 41, 125-132. doi:10.1016/j. ijhm.2014.05.004.

Kim, T., Kim, W. G., \& Kim, H. B. (2009). The effects of perceived justice on recovery satisfaction, trust, word-of-mouth, and revisit intention in upscale hotels. Tourism Management, $\quad 30(1), \quad$ 51-62. doi:10.1016/j. tourman.2008.04.003.

Komunda, M., \& Osarenkhoe, A. (2012). Remedy or cure for service failure? Effects of service recovery on customer satisfaction and loyalty. Business Process Management, 18(1), 82-103. doi:10.1108/14637151211215028.

Krishna, A., Dangayach, G. S., \& Sharma, S. (2014). Service recovery paradox: the success parameters. Global Business Review, 15(2), 263-277. doi:10.1177/0972150914523567.

Kwon, S. Y., \& Jang, S. C. (2012). Effects of compensation for service recovery: From the equity theory perspective. International Journal of Hospitality Management, 31(4), 1235-1243. doi:10.1016/j.ijhm.2012.03.002.

Lewis, B. R., \& McCann, P. (2004). Service failure and recovery: evidence from the hotel industry. International Journal of Contemporary Hospitality Management, 16(1), 6-17. doi:10.1108/09596110410516516.

Lin, H. H., Wang, Y. S., \& Chang, L. K. (2011). Consumer responses to online retailer's service recovery after a service failure: a perspective of justice theory. Managing Service Quality, 21(5), 511-534. doi:10.1108/09604521111159807.

Liu, S. Q., \& Matilla, A. S. (2015). "I Want to Help" versus "I Am Just Mad": How Affective Commitment Influences Customer Feedback Decisions. Cornell Hospitality Quarterly, 56(2), 213-222. doi:10.1177/1938965515570939.

Marimon, F., Petnji Yaya, L. H., \& Casadesus, M. (2012). Impact of e-quality and service recovery on loyalty: a study of e-banking in Spain. Total Quality Management \& Business Excellence, 23(7-8), 769-787. doi:10.1080/147 83363.2011.637795.

Maxham, J. G., \& Netemeyer, R. G. (2002). A longitudinal study of complaining customers' evaluations of multiple service failures and recovery efforts. Journal of Marketing, 66(4), 57-71. doi:10.1509/jmkg.66.4.57.18512.

McCollough, M. A. (2010). The recovery paradox: the effect of recovery performance 
and service failure severity on post-recovery customer satisfaction. Academy of Marketing Studies Journal, 14(2), 89-104.

Michel, S., Bowen, D., \& Johnston, R. (2009). Why service recovery fails: tensions among customer, employee, and process perspectives. Journal of Service Management, 20(3), 253-273. doi:10.1108/09564230910964381.

Miller, J. L., Craighead, C. W., \& Karwan, K. R. (2000). Service recovery. A framework and empirical investigation. Journal of Operations Management, 18(4), 387-400. doi:10.1016/ s0272-6963(00)00032-2.

Molinari, L. K., Abratt, R., \& Dion, P. (2008). Satisfaction, quality and value and effects on repurchase and positive word-of-mouth behavioral intentions in a B2B services context. Journal of Services Marketing, 22(5), 363-373. doi:10.1108/08876040810889139.

Moreno, S., Hudson, S., \& Aguilar, T. (2006). The influence of service recovery and loyalty on perceived service quality: a study of hotel customers in Spain. Journal of Hospitality \& Leisure Marketing, 14(2), 47-68. doi:10.1300/ j150v14n02_04.

Morrisson, O., \& Huppertz, J. W. (2010). External Equity, Loyalty Program Membership and Service Recovery. Journal of Services Marketing, 24(3), 244-254. doi:10.1108/08876041011040640.

Mount, D. J., \& Mattila, A. (2009). The relationship of reliability and recovery to satisfaction and return intent at the hotel unit level. Journal of Quality Assurance in Hospitality \& Tourism, 10(4), 301-310. doi:10.1080/15280080903183276.

Mount, D. J. (2012). Putting the dollar signs on quality: the benefits of service recovery in the hotel industry. Journal of Quality Assurance in Hospitality \& Tourism, 13(2), 152-163. doi:10.1080/1528008x.2012.643189.

Nunnally, J. C., \& Bernstein, I. H. (1994). Psychometric Theory. New York: McGraw Hill.

Nyer, P. U. (2000). An investigation into whethercomplainingcancauseincreasedconsumer satisfaction. Journal of Consumer Marketing, 17(1), 9-19. doi:10.1108/07363760010309500.

Oliver, R. L. (1980). A cognitive model of the antecedents and consequences of satisfaction decisions. Journal of Marketing Research, 17(4), 460-469. doi:10.2307/3150499.

Oliver, R. L. (2010). Satisfaction: a behavioral perspective on the consumer. New York: M. E. Shape.
Petnji, L. H., Marimon, F., \& Casadesus, M. (2013). Can ISO 9001 improve service recovery? Industrial Management \& Data Systems, 113(8), 1206-1221. doi:10.1108/imds-03-2013-0150.

Reynolds, K. E., \& Beatty, S. E. (1999). Customer benefits and company consequences of customer-salesperson relationships in retailing. Journal of Retailing, 75(1), 11-32. doi:10.1016/s0022-4359(99)80002-5.

Río, A. B., Vázquez, R., \& Díaz, A. M. (2009). Satisfaction with service recovery: perceived justice and emotional responses. Journal of Business Research, 62(8), 775-781. doi:10.1016/j.jbusres.2008.09.015.

Sánchez, I., Pieters, R., Zeelenberg, M., \& Bigné, E. (2012). When Satisfied Consumers Do Not Return: Variety Seeking's Effect on Short- and Long-Term Intentions. Psychology \& Marketing, 29(1), 15-24. doi:10.1002/mar.20431.

Sengupta, A. S., Balaji, M. S., \& Krishnan, B. C. (2015). How customers cope with service failure? Astudy of brand reputation and customer satisfaction. Journal of Business Research, 68, 665-674. doi:10.1016/j.jbusres.2014.08.005.

Singhal, S., Krishna, A., \& Lazarus, D. (2013). Service failure magnitude and paradox: a banking perspective. Journal of Relationship Marketing, 12(3), 191-203. doi:10.1080/153326 67.2013.836027.

Sparks, B. A., \& Callan, V. J. (1996). Service breakdowns and service evaluation: The role of customer attributions. Journal of Hospitality \& Leisure Marketing, 4(2), 3-24. doi:10.1300/ j150v04n02_02.

Tax, S. S., \& Brown, S. W. (2000). Service recovery: research insights and practices. In T. A. Swartz, \& D. lacobucci (Eds.), Handbook of Services Marketing \& Management. Thousand Oaks, CA: Sage Publications.

Varela-Neira, C., Vázquez-Casielles, R., \& Iglesias-Argüelles, V. (2010). The effects of customer age and recovery strategies in a service failure setting. Journal of Financial Services Marketing, 15(2), 32-48. doi:10.1057/ fsm.2010.2.

Vázquez-Casielles, R., Suárez-Álvarez, L., \& Díaz-Martín, A. M. (2010). Perceived justice of service recovery strategies: impact of customer satisfaction and quality relationship. Psychology \& Marketing, 27(5), 487-509. doi:10.1002/mar.20340.

Vildová, E., Martinčík, D., Tlučhoř, J., \& Jakubíková, D. (2015). Measuring customer 
satisfaction and loyalty in spa companies. E\&M Ekonomie a Management, 18(1), 151-168. doi:10.15240/tul/001/2015-1-012.

Weber, K., \& Sparks, B. (2010). Service failure and recovery in a strategic airline alliance context: interplay of locus of service failure and social identity. Journal of Travel \& Tourism Marketing, 27(6), 547-564. doi:10.1080/10548408.2010.507137.

Westbrook, R. A. (1987). Product consumption-based affective responses and postpurchase processes. Journal of Marketing Research, 24(3), 258-270. doi:10.2307/3151636.

Wirtz, J., \& Mattila, A. (2004). Consumer responses to compensation, speed of recovery and apology after a service failure. International Journal of Service Industry Management, 15(2), 150-166. doi:10.1108/09564230410532484.

Yoon, S. J., \& Kim, J. H. (2000). An empirical validation of a loyalty model based on expectation disconfirmation. Journal of Consumer Marketing, 17(2), 120-136. doi:10.1108/07363760010317196.

Zeithaml, V. A., Parasuraman, A., \& Berry, L. L. (1990). Delivering service quality: Balancing customer perceptions and expectations. New York: Free Press.

Zeithaml, V. A., Berry, L. L., \& Parasuraman, A. (1993). The nature and determinants of customer expectations of service. Journal of the Academy of Marketing Science, 21(1), 1-12. doi:10.1177/0092070393211001.
Zeithaml, V. A., Berry, L. L., \& Parasuraman, A. (1996). The behavioural consequences of service quality. Journal of Marketing, 60(2), 31-46. doi:10.2307/1251929.

Assist. Prof. Estrella Díaz, Ph.D. Universidad de Castilla-La Mancha Facultad de Derecho y Ciencias Sociales estrella.diaz@uclm.es

Assist. Prof. Mar Gómez, Ph.D. Universidad de Castilla-La Mancha Facultad de Ciencias Jurídicas y Sociales and

Universidad Autónoma de Chile Facultad de Ciencias Empresariales mariamar.gomez@uclm.es

Assoc. Prof. David Martín-Consuegra, Ph.D. Universidad de Castilla-La Mancha Facultad de Derecho y Ciencias Sociales and Universidad Autónoma de Chile Facultad de Ciencias Empresariales david.martin@uclm.es

Assoc. Prof. Arturo Molina, Ph.D. Universidad de Castilla-La Mancha Facultad de Ciencias Jurídicas y Sociales and Universidad Autónoma de Chile Facultad de Ciencias Empresariales arturo.molina@uclm.es 


\section{Appendix 1: Measurement items}

\begin{tabular}{|c|c|}
\hline Dimensions & Items \\
\hline Communication & $\begin{array}{l}\text { COM 1: The XXX Hotel employees I dealt with, communicated clearly when } \\
\text { providing feedback about my complaint. } \\
\text { COM 2: When I complained about poor service, the XXX Hotel employees } \\
\text { asked questions to help clarify the situation. } \\
\text { COM 3: The XXX Hotel employees I dealt with, were very understanding. } \\
\text { COM 4: The XXX Hotel employees I dealt with, were reliable } \\
\text { COM 5: The XXX Hotel employees I dealt with, were honest in their endeavors } \\
\text { to solve my problem. }\end{array}$ \\
\hline Training & $\begin{array}{l}\text { TRA 1: The employee I complained to first, was able to solve my problem. } \\
\text { TRA 2: The employee I complained to first, had to find someone else to solve } \\
\text { my problem. } \\
\text { TRA 3: My complaint was passed on from one employee to the next. }\end{array}$ \\
\hline Response & $\begin{array}{l}\text { RES 1: XXX Hotel informed me about the progress made to solve my problem. } \\
\text { RES 2: XXX Hotel sent me a written apology. }\end{array}$ \\
\hline Apology & $\begin{array}{l}\text { APO 1: XXX Hotel apology for the service fail. } \\
\text { APO 2: XXX Hotel ensured that I am fine. } \\
\text { APO 3: The XXX Hotel employees I dealt with, were polite. }\end{array}$ \\
\hline Explanation & $\begin{array}{l}\text { EXP 1: XXX Hotel provided me with an explanation of why the problem had } \\
\text { occurred. } \\
\text { EXP 2: The XXX Hotel employees I dealt with, provided a satisfactory } \\
\text { explanation of why the problem had occurred. }\end{array}$ \\
\hline Tangible features & $\begin{array}{l}\text { TAN 1: The XXX Hotel employees I dealt with, were well dressed. } \\
\text { TAN 2: The XXX Hotel employees I dealt with, work in a tidy, professional } \\
\text { environment. }\end{array}$ \\
\hline Satisfaction & $\begin{array}{l}\text { SAT 1: I am satisfied with XXX Hotel. } \\
\text { SAT 2: XXX Hotel meets my expectations. } \\
\text { SAT 3: My choice was wise. } \\
\text { SAT 4: The overall quality of a service offered by XXX Hotel is excellent. } \\
\text { SAT 5: I think that I selected the right hotel. } \\
\text { SAT 6: I am not happy with XXX Hotel. }\end{array}$ \\
\hline $\begin{array}{l}\text { Repurchase } \\
\text { intention }\end{array}$ & $\begin{array}{l}\text { INT 1: The ability of XXX Hotel to handle conflict well will influence my } \\
\text { repurchase intention. } \\
\text { INT 2: I feel committed to XXX Hotel. } \\
\text { INT 3: After my experience with XXX Hotel, I will not change to other hotels. } \\
\text { INT 4: In the future, I intend to book XXX Hotel. }\end{array}$ \\
\hline Word-of-mouth & $\begin{array}{l}\text { WOM 1: I would recommend XXX Hotel to my friends. } \\
\text { WOM 2: I would spread positive word-of-mouth about XXX Hotel. } \\
\text { WOM 3: If my friends were looking for a hotel, I would tell them to try XXX } \\
\text { Hotel. }\end{array}$ \\
\hline
\end{tabular}

Source: Adapted from Boshoff (2005), Reynolds and Beatty (1999), Maxham and Netemeyer (2002) and Zeithaml, Berry and Parasuraman (1996) 


\title{
Abstract
}

\section{THE EFFECTS OF PERCEIVED SATISFACTION WITH SERVICE RECOVERY EFFORTS: A STUDY IN A HOTEL SETTING}

\author{
Estrella Díaz, Mar Gómez, David Martín-Consuegra, Arturo Molina
}

In the service industry, the importance of achieving the satisfaction of all involved agents is widely recognized. It is important to note that within the service sector, the hospitality sector involves a high degree of personal contact between hotel staff and customers, during which various misunderstandings can result in service failures. Therefore, instruments that enable learning about and solving problems emerging from customers now serve as one of the most important elements of the hospitality industry. In this context, the objective of answering the call for more studies investigating the effectiveness of recovery efforts and discovering their effects to perceived customer satisfaction, following a service recovery process, and customer behavior outcomes towards a hotel which had dropped the ball but later offered a solution. A structural equation model using a sample of 274 valid questionnaires, obtained from hotel establishment customers who had experienced failed service provisions and who had shown their discontent with these services, was used to examine these issues. The results confirm a significant and positive effect between the analyzed relations and also reinforce the importance of recovery efforts on satisfaction in service recovery and also determine the impact of that perceived satisfaction on behavioral outcomes of the affected consumers. Additionally, the empirical results show that communication and explanation are the dimensions of importance to consumers when they report a service failure to a service firm. Based on these results, this study recommends designing recovery process in such a way to get maximum advantage of this phenomenon. Therefore, organizations should offer dissatisfied customers with the option to choose among various recovery options.

Key Words: Hotels; repurchase intention; satisfaction; service recovery; word-of-mouth.

JEL Classification: M31, L83.

DOI: 10.15240/tul/001/2017-4-014 